\title{
Communication \\ Increased Activities against Biofilms of the Pathogenic Yeast Candida albicans of Optimized Pom-1 Derivatives
}

\author{
Valerie Amann ${ }^{1,+}$, Ann-Kathrin Kissmann ${ }^{1,+}$, Markus Krämer ${ }^{1,+}{ }^{+}$, Imke Krebs ${ }^{1}$, Julio A. Perez-Erviti ${ }^{2}$, \\ Anselmo J. Otero-Gonzalez ${ }^{2}$ (D) Fidel Morales-Vicente ${ }^{3,4}$, Armando Rodríguez ${ }^{5,6} \mathbb{C D}_{\text {, Ludger Ständker }}{ }^{(\mathbb{D})}$, \\ Tanja Weil ${ }^{7}$ and Frank Rosenau $1,7, *$ i
}

check for updates

Citation: Amann, V.; Kissmann, A.-K.; Krämer, M.;

Krebs, I.; Perez-Erviti, J.A.;

Otero-Gonzalez, A.J.;

Morales-Vicente, F.; Rodríguez, A.; Ständker, L.; Weil, T.; et al. Increased Activities against Biofilms of the Pathogenic Yeast Candida albicans of Optimized Pom-1 Derivatives. Pharmaceutics 2022, 14, 318.

https: / /doi.org/10.3390/

pharmaceutics14020318

Academic Editors: Jennifer Fiegel and Sanna Maria Sillankorva

Received: 16 December 2021

Accepted: 23 January 2022

Published: 28 January 2022

Publisher's Note: MDPI stays neutral with regard to jurisdictional claims in published maps and institutional affiliations.

Copyright: (C) 2022 by the authors. Licensee MDPI, Basel, Switzerland. This article is an open access article distributed under the terms and conditions of the Creative Commons Attribution (CC BY) license (https:// creativecommons.org/licenses/by/ $4.0 /)$.
1 Institute of Pharmaceutical Biotechnology, Ulm University, Albert-Einstein-Allee 11, 89081 Ulm, Germany; valerie.amann@uni-ulm.de (V.A.); ann-kathrin.kissmann@uni-ulm.de (A.-K.K.); markus-1.kraemer@uni-ulm.de (M.K.); imke.krebs@uni-ulm.de (I.K.)

2 Center for Protein Studies, Faculty of Biology, University of Havana, 25 Str. and I Str., La Habana 10400, Cuba; julio.perez@fbio.uh.cu (J.A.P.-E.); aotero@fbio.uh.cu (A.J.O.-G.)

3 General Chemistry Department, Faculty of Chemistry, University of Havana, Zapata y G, La Habana 10400, Cuba; femvicente@gmail.com

4 Synthetic Peptides Group, Center for Genetic Engineering and Biotechnology, La Havana 10600, Cuba

5 Core Facility for Functional Peptidomics, Ulm Peptide Pharmaceuticals (U-PEP), Faculty of Medicine, Ulm University, 89081 Ulm, Germany; armando.rodriguez-alfonso@uni-ulm.de (A.R.); ludger.staendker@uni-ulm.de (L.S.)

6 Core Unit of Mass Spectrometry and Proteomics, Faculty of Medicine, Ulm University, 89081 Ulm, Germany

7 Max Planck Institute for Polymer Research Mainz, Ackermannweg 10, 55128 Mainz, Germany; weil@mpip-mainz.mpg.de

* Correspondence: frank.rosenau@uni-ulm.de

+ These authors contributed equally to this paper.

\begin{abstract}
Antimicrobial peptides (AMPs) are an alternative group for the therapy of infectious diseases, with activity against a wide range of diverse pathogens. However, classical AMPs have significant side effects in human cells due to their unspecific pore formation in biomembranes. Nevertheless, AMPs are promising therapeutics and can be isolated from natural sources, which include sea and freshwater molluscs. The AMPs identified in these organisms show promising antimicrobial activities, as pathogens are mainly fought by innate defence mechanisms. An auspicious candidate among molluscs is the Cuban freshwater snail Pomacea poeyana, from which the peptides Pom- 1 and Pom-2 have been isolated and studied. These studies revealed significant antimicrobial activities for both AMPs. Based on the activities determined, Pom-1 was used for further optimization. In order to meet the emerging requirements of improved anti-biofilm activity against naturally occurring Candida species, the six derivatives Pom-1A to F were developed and investigated. Analysis of the derivatives acting on the most abundant naturally occurring Candida yeast Candida albicans (C. albicans) revealed a strong anti-biofilm activity, especially induced by Pom-1 B, C, and D. Furthermore, a moderate decrease in the metabolic activity of planktonic yeast cells was observed.
\end{abstract}

Keywords: antimicrobial peptides; Candida albicans; antibiofilm activity

\section{Introduction}

A more than considerable amount of $75 \%$ of all women contract a fungal infection with the pathogenic genus Candida, like C. parapsiolosis, C. glabrata, or C. tropicalis, during their lifetime. In 85-95\% of cases, these infections are caused by C. albicans [1]. In natural environments, many microorganisms, including yeast, form biofilms attached to abiotic and biotic surfaces. Yeasts adhere to surfaces, proliferate, and produce an extracellular matrix (ECM) forming microcolonies that mature (Figure 1). Cells disperse from the mature biofilms that adhere to surfaces and start a new cycle of biofilm formation [2]. This 
mechanism is a strategy of yeast cells to increase their physical stability to antifungal drugs, thus increasing the morbidity and mortality of infected patients [3-7].

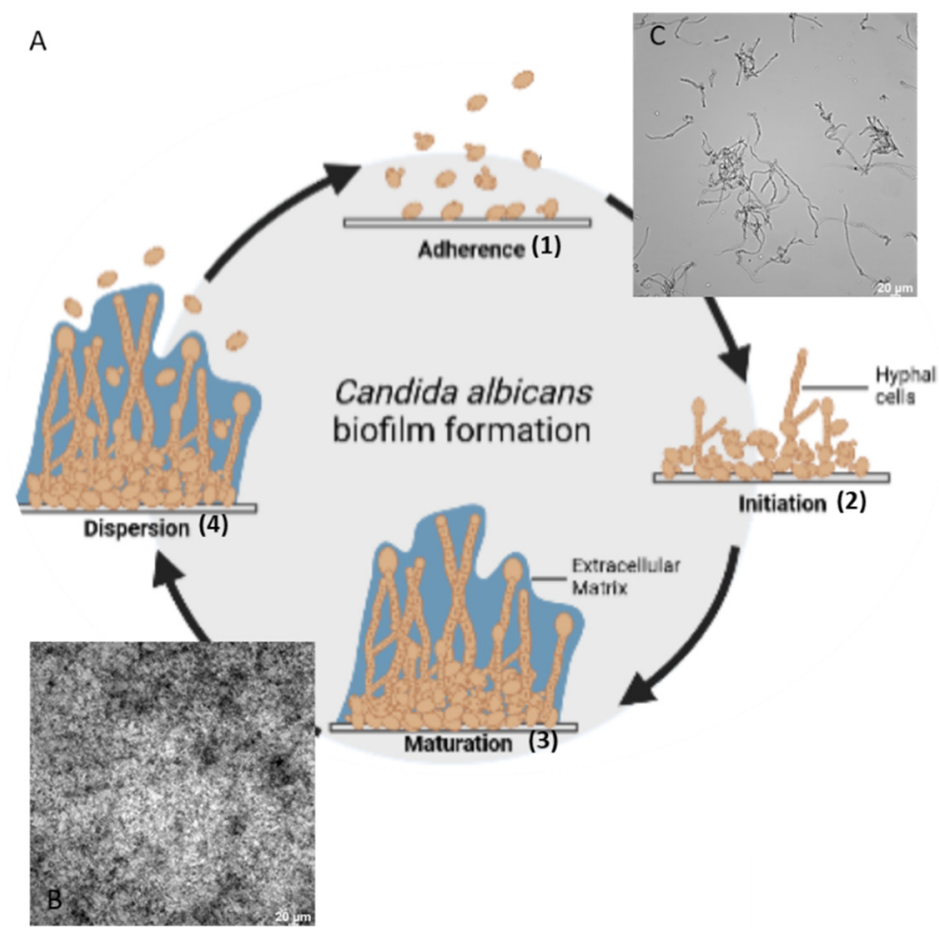

Figure 1. Overview of the biofilm formation of the yeast $C$. albicans structured in four steps (A). (1) Attachment of planktonic yeast cells to a surface, (2) aggregation and proliferation of cells, (3) formation of a mature biofilm with a species-specific ECM, (4) and detachment of yeast cells from the biofilm to form further biofilms. Micrographs photographed with transmission light in using a Leica DMi8 coded (Leica Microsystems CMS GmbH, Wetzlar, Germany) microscope after $24 \mathrm{~h}$ of growth at $37^{\circ} \mathrm{C}$. C. albicans biofilm (B) and planktonic cells (C).

Conventional treatment of Candida infections is based on (targeted) pharmaceutical therapy using compounds like the azole antimycotic fluconazole, which inhibits the enzyme 14- $\alpha$-demethylase and thus prevents the formation of ergosterol, which is responsible for membrane stability [8].

However, since 2016, the Clinical Practice Guideline from Management of Candidiasis from the Infectious Disease Society of America no longer recommends the use of fluconazole as first-line treatment for less sensitive strains of the genus Candida, as these yeasts can often quickly develop high tolerances $[9,10]$. Several mechanisms, such as binding of the azole to $\beta-1,3$-glucan at the ECM and its exclusion by azole efflux pumps or mutations in the structure or expression of the target protein, have been identified to be decisive factors triggering resistance [11-15]. Due to these characteristics, resistant Candida species are classified as a "serious threat" by the CDC of the U.S. Department of Health and Human Services (Centers for Disease Control and Prevention (CDC), 2019) [16].

Antimicrobial peptides (AMPs) may represent an alternative to these conventional drugs sd they do not bind specifically to a protein of the pathogen to inhibit its enzymatic activity, but can modify their physical or chemical properties and alter the membrane structure and the physiological integrity of the pathogen. The key factor for this efficacy lies in their intrinsic amphiphilic character, normally with both cationic and hydrophobic residues along the peptide sequence $[17,18]$. As these peptides are found in virtually all life forms, nature appears to offer an almost unlimited diversity that can provide medicine with promising new molecules for the upcoming area of short running potent classical antibiotics and antimycotics. Sea- and fresh-water molluscs, which have been identified as one of the most diverse phyla on Earth, carry these AMPs in their innate immune system to fight off 
viruses, bacteria, yeasts, and parasites [19]. The AMPs Pom-1 and Pom-2 were isolated from the freshwater snail Pomacea poeyana (Pilsbry, 1927), and show an $\alpha$-helical structure in a membrane-like environment [1] (Figure 2). These peptides have been shown to be effective not only against the pathogenic bacteria Pseudomonas aeruginosa, Klipsella pneumonia, and Listeria monocytogenes [20], but also with low activity against planktonic and high activity cells of yeasts of the genus Candida. Pom-1 was used for optimization as it exhibited a higher antimicrobial activity than Pom-2 [21].

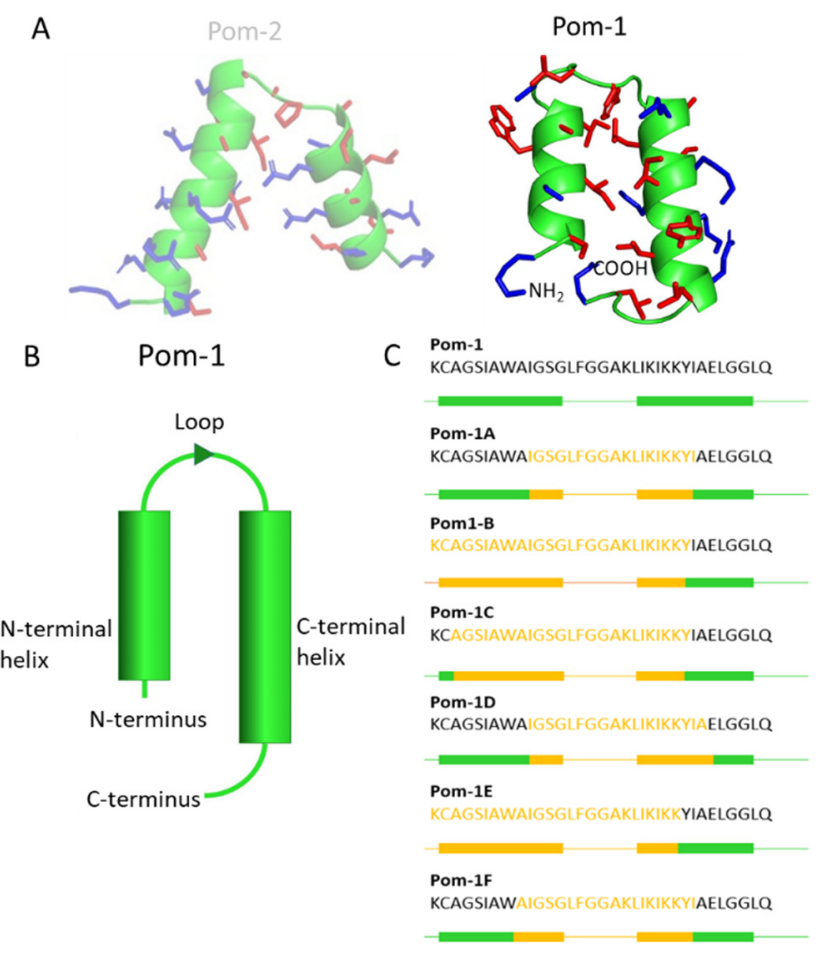

Figure 2. Representation of the Pom-1 and Pom-2 (in transparent, as not used further in this study) structure by a ribbon model with corresponding side chains (A) and schematic ribbon model modeled with QUARK and SwissModel (B), as well as the amino acid sequence with schematic representation of the $\alpha$-helical structure of Pom-1 (green) in comparison to the optimized (i.e., truncated) derivatives Pom-1A to F (yellow) (C). In this illustration, the boxes indicate the $\alpha$-helices, while the lines represent the loops.

This peptide is a 34-amino acid-long fragment of Closticin 574, a bacteriocin with a known antibacterial activity against several Clostridium spp. [22]. According to structure prediction (QUARK and SwissModel), Pom-1 consists of two $\alpha$-helices (shorter N-terminal $\alpha$-helix with predominantly hydrophobic properties and longer C-terminal $\alpha$-helix with amphiphilic properties), which are connected by a short loop. Based on this peptide, six derivatives, Pom-1A to F (Figure 2), were selected after in silico generation from Pom-1 and further ranking according to the highest AMP prediction probability (no specific AMP activity/effect was further predicted). In Figures 3 and 4, it is shown that while Pom-1B and Pom-1E have a higher inhibitory effect on planktonic cells of C. albicans than Pom-1, all peptides have a better antifungal effect on biofilm formation, while Pom-1B, C, and D have an extraordinary reduction in the biofilm formation of $C$. albicans. In addition, only marginal cytotoxicity against human dermal fibroblasts (HDF) [23] and adenocarcinomic human alveolar basal epithelial cells (A549) [24] was detected with these three peptides.

\section{Materials and Methods}

\subsection{Materials}

Acetic acid, agar-agar, crystal violet, glucose, 3-(N-morpholino) propanesulfonic acid (MOPS), peptone, and yeast extract were ordered from Carl Roth GmbH (Karlsruhe, 
Germany), and RPMI-1640 medium supplemented with L-glutamine was purchased from Thermo Fisher Scientific (Waltham, MA, USA). Fluconazole was obtained from Merck KGaA (Darmstadt, Germany) and resazurin sodium salt was sourced from Sigma-Aldrich Chemie GmbH (Steinheim, Germany). Dulbecco's modified eagle medium (DMEM) supplemented with fetal bovine serum (FBS; $10 \%(w / v))$, penicillin-streptomycin $\left(100 \mathrm{U} \mathrm{mL}^{-1}\right.$, $1 \%(w / v)$ ), eagle's minimum essential medium non-essential amino acids (MEM NEAA) $(1 \%(w / v))$, and accutase ${ }^{\circledR}$ solution were ordered from Life Technologies (Carlsbad, CA, USA). Phosphate-buffered saline (PBS) was sourced from Life Technologies (Carlsbad, CA, USA).

\subsection{Methods}

\subsubsection{Cultivation of C. albicans}

Candida albicans (ATCC 90028) was sourced from the IPK Medical Mycology Laboratory and cultured on Sabouraud dextrose agar $(40 \mathrm{~g} / \mathrm{L}$ glucose, $10 \mathrm{~g} / \mathrm{L}$ peptone, $20 \mathrm{~g} / \mathrm{L}$ agar, $\mathrm{pH}$ 5.6). For the suspension cultures, $10 \mathrm{~mL}$ of RPMI-1640 medium supplemented with L-glutamine (Thermo Fisher Scientific (Waltham, MA, USA)) was inoculated with a single colony in a $100-\mathrm{mL}$ Erlenmayer flask and was grown at $37^{\circ} \mathrm{C}$ with orbital shaking at $150 \mathrm{rpm}$ for $16 \mathrm{~h} \mathrm{[21].}$

\subsubsection{Peptide Optimization}

Pom- 1 fragments (10 or more aa residues) were generated in silico by a Protein Digestion Simulator, https:/ / pnnl-comp-mass-spec.github.io/Protein-Digestion-Simulator/ from PNNL and the Protein-Digestion-Simulator GitHub repository (accessed on 10 February 2021) [25], and were then evaluated by the CAMPR3-Predict Antimicrobial Peptide tool http:/ /www.camp.bicnirrh.res.in/predict/ (accessed on 10 February 2021) [26], Peptide AMP Scanner, https:/ /www.dveltri.com/ascan/v2/ascan.html (accessed on 10 February 2021) [27] and iAMPpred, http:/ / cabgrid.res.in:8080/amppred/server.php (accessed on 10 February 2021) [28]. The results were merged and the AMP prediction probability (no specific AMP activity/effect was further predicted) values from all servers were averaged for every sequence. A rank list was organized by decreasing order of AMP prediction probability (Table S1). Six peptides (Pom-1A to F) with the highest values were synthesized automatically in a $0.10 \mathrm{mmol}$ scale using standard Fmoc solid phase peptide synthesis techniques with the microwave synthesizer Liberty blue (CEM GmbH, Kamp-Lintfort, Germany), as described previously [20].

\subsubsection{Resazurin-Reduction-Assay/Viability-Assay}

The viability of treated C. albicans cells with Pom-1A to F was determined according to the Clinical and Laboratory Standards Institute guidelines (M27-A3) for the broth microdilution assay [29]. For this, $2.5 \times 10^{3}$ yeast cells were incubated in $200 \mu \mathrm{L}$ of RPMI-1640 medium (supplemented with L-glutamine) in the presence of various concentrations of Pom-1A to $\mathrm{F}(2.5-20 \mu \mathrm{g} / \mathrm{mL})$ in flat-bottomed polystyrene microtiter plates with 96 wells (Sarstedt AG and Co. KG, Nümbrecht, Germany) at $37^{\circ} \mathrm{C}$ with shaking at $900 \mathrm{rpm}$ on an Eppendorf shaker. Quantitation of viable yeast cells was performed using a Resazurin-reduction-Assay [30]. For this, yeast cells were incubated with $20 \mu \mathrm{L}$ of $0.15 \mathrm{mg} / \mathrm{mL}$ resazurin solution for $2 \mathrm{~h}$. During this time, the viable cells were able to reduce the resazurin to resorufin. With fluorescence measurements at an excitation wavelength of 535 and an emission of $595 \mathrm{~nm}$ with a Tecan infinite F200 microplate reader (Tecan Group Ltd., Männedorf, Switzerland) the amount of converted resorufin could be determined, and thus the viability of the cells could be quantified. The data obtained were subsequently identified in a Hill nonlinear dose-response equation and the semi-inhibitory concentration $\left(\mathrm{IC}_{50}\right)$ could be determined, at which the cell viability was reduced by $50 \%$ compared to the untreated control. In addition, after incubation, $1 \mu \mathrm{L}$ cell suspension was taken from each well of the microtiter plate to visually confirm the graphical results in a plate spot assay [31]. For this purpose, a dilution series was prepared for each sample in RPMI 1640 
medium and $1 \mu \mathrm{L}$ was added to Sabouraud agar plates, which were then incubated for $24 \mathrm{~h}$ at $37^{\circ} \mathrm{C}$, respectively.

\subsubsection{Biofilm Formation and Crystal-Violet-Assay/Biomass-Quantification}

The analysis of the antifungal effect of the peptides on biofilm followed the same conditions as described previously [32,33]. In brief, $2.5 \times 10^{3}$ yeast cells were incubated in $200 \mu \mathrm{L}$ RPMI-1640 medium with L-glutamine in flat-bottomed polystyrene microtiter plates with 96 wells (Sarstedt AG and Co. KG, Nümbrecht, Germany) with the respective peptides at different concentrations $(2.5-20 \mu \mathrm{g} / \mathrm{mL})$ for $24 \mathrm{~h}$ at $37^{\circ} \mathrm{C}$, but without agitation. The quantification of the biofilm took place due to a crystal violet assay, which was originally developed by George $\mathrm{O}^{\prime}$ Toole for bacteria $[32,34]$ and was adapted for Candida biofilms $[5,32,34,35]$. For this, the planktonic phase in the wells was removed and the biofilms were washed twice with $200 \mu \mathrm{L}$ of demineralized water. Subsequently, the cells in the biofilm were stained for $15 \mathrm{~min}$ with $200 \mu \mathrm{L}$ of a $0.1 \%(w / v)$ crystal violet solution. The solution was then removed again and the stained cells were washed twice with $200 \mu \mathrm{L}$ of demineralized water. Then, the biofilms in the microtiter plate were dried for $24 \mathrm{~h}$ at $25^{\circ} \mathrm{C}$. These were then mixed with $200 \mu \mathrm{L}$ of $30 \%$ acetic acid. After $15 \mathrm{~min}$, the stained solution was transferred to a new microtiter plate and the absorbance at $560 \mathrm{~nm}$ was measured using a Tecan infinite F200 microplate reader. The data obtained were then graphically identified using a Hill non-linear dose-response equation and the semi-inhibitory concentration $\left(\mathrm{IC}_{50}\right)$ was determined, at which $50 \%$ of the biofilm was not formed compared to the untreated control.

\subsubsection{Cell Culture}

Adenocarcinomic human alveolar basal epithelial cells A549 [24] and human dermal fibroblasts HDF [23] were used for the experiments. The cultivation of these cells was performed in DMEM supplemented with FBS $(10 \%(w / v))$, MEM NEAA $(1 \%(w / v))$, and penicillin-streptomycin $(100 \mathrm{U} \mathrm{mL}-1,1 \%(w / v))$ in a $37^{\circ} \mathrm{C}$ incubator containing $5 \% \mathrm{CO}_{2}$.

\subsubsection{Passaging Adherend Cell Cultures}

Accutase was used to seed the adherent cell cultures. First, the medium was preheated with additives at $37^{\circ} \mathrm{C}$. Then, the medium in the culture flask was removed and 2.5 to $5 \mathrm{~mL}$ accutase was immediately added. The flask with accutase was incubated for 5 to $10 \mathrm{~min}$ at room temperature until the cells had formed a rounded shape. For detaching the cells from the ground, the culture flask was knocked against the back of the hand. A desired cell number was aliquoted into a new culture flask containing $5 \mathrm{~mL}$ DMEM medium with supplements and incubation at $37^{\circ} \mathrm{C}$ containing $5 \% \mathrm{CO}_{2}$.

\subsubsection{Viability-Assays for Cell Cultures}

A resazurin assay was performed to detect cell viability. For this, $2 \times 10^{4}$ cells per well were incubated for $48 \mathrm{~h}$ in a 96-well-plate in DMEM with supplements $(100 \mu \mathrm{L})$ and different peptide concentrations $(2.5 \mu \mathrm{g} / \mathrm{mL}, 20 \mu \mathrm{g} / \mathrm{mL})$ at $37^{\circ} \mathrm{C}$ containing $5 \% \mathrm{CO}_{2}$. Afterwards, $20 \mu \mathrm{L}$ resazurin $(0.15 \mathrm{mg} / \mathrm{mL})$ was added to each well and was incubated for $24 \mathrm{~h}$ at $37^{\circ} \mathrm{C}$ containing $5 \% \mathrm{CO}_{2}$. Thereafter, the fluorescence of resorufin was measured with a Tecan infinite F200 microplate reader (Tecan Group Ltd., Männedorf, Switzerland) at an excitation wavelength of $535 \mathrm{~nm}$ and an emission wavelength of $595 \mathrm{~nm}$.

\subsubsection{ExPASy ProtParam}

To determine the peptide properties of the Pom-1 derivatives, ProtParam analysis tool (Expasy) was used [36]. This tool calculates the GRAVY (Grand average of hydropathicity) (Formula 1) and the Amphihilic Index (Formula 2) of the desired peptide according to the following formulas.

$$
\text { GRAVY }=\frac{\text { sum of hydropathy values of all the amino acid }}{\text { number of resedues in the sequence }}
$$




$$
\text { Amphipilic Index }=X(\text { Ala })+a \times X(\text { Val })+b \times[X(\text { Ile })+X(\text { Leu })]
$$

To determine the amphiphilic index, the mole percentages $(X)$ of the amino acids alanine (Ala), valine (Val), isoleucine (Ile), and leucine (Leu) were added together, taking into account the relative volume of valine side chains $(a=2.9)$ and Leu/Ile side chains $(b=3.9)$ of Ala.

\subsubsection{Statistical Analysis}

With Student's $t$-test, the statistical significance was tested. $p$ values $<0.05$ were considered significant, ${ }^{*}$ denotes $p<0.05,{ }^{* *} p<0.01$ and ${ }^{* *} p<0.001$. Standard deviations were represented as error bars.

\section{Results}

\subsection{Pom-1 A-F Are Active against Planctonic Cells}

To determine the antifungal effect of the peptide derivatives on planktonic $C$. albicans cells, different concentrations $(2.5-20 \mu \mathrm{g} / \mathrm{mL})$ of the peptides were applied to fixed cell numbers $\left(2.5 \times 10^{3}\right.$ cells per well $)$ and were incubated for $24 \mathrm{~h}$ in a suspension microtiter plate. A resazurin reduction assay was then performed to determine the cell viability, where the growth of the untreated cell was used as the reference value.

The results of the resazurin reduction assay for the treated planktonic $C$. albicans cells with Pom-1, Pom-1A to F, and fluconazole did not show 100\% inhibition of cell viability for any agent in the concentration range of $0-20 \mu \mathrm{g} / \mathrm{mL}$ (Figure 3A). The peptide Pom-1B and Pom-1E, similar to the commercially used fungicide fluconazole, showed up to $70 \%$ inhibition of cell viability at a concentration of $20 \mu \mathrm{g} / \mathrm{mL}$. Furthermore, Pom- 1 A showed approximately $50 \%$ inhibition of cell viability at the same concentration, while all other derivatives (Pom-1C, D, and E), as well as Pom-1, did not even reach this $50 \%$ inhibition of C. albicans cell viability.

A
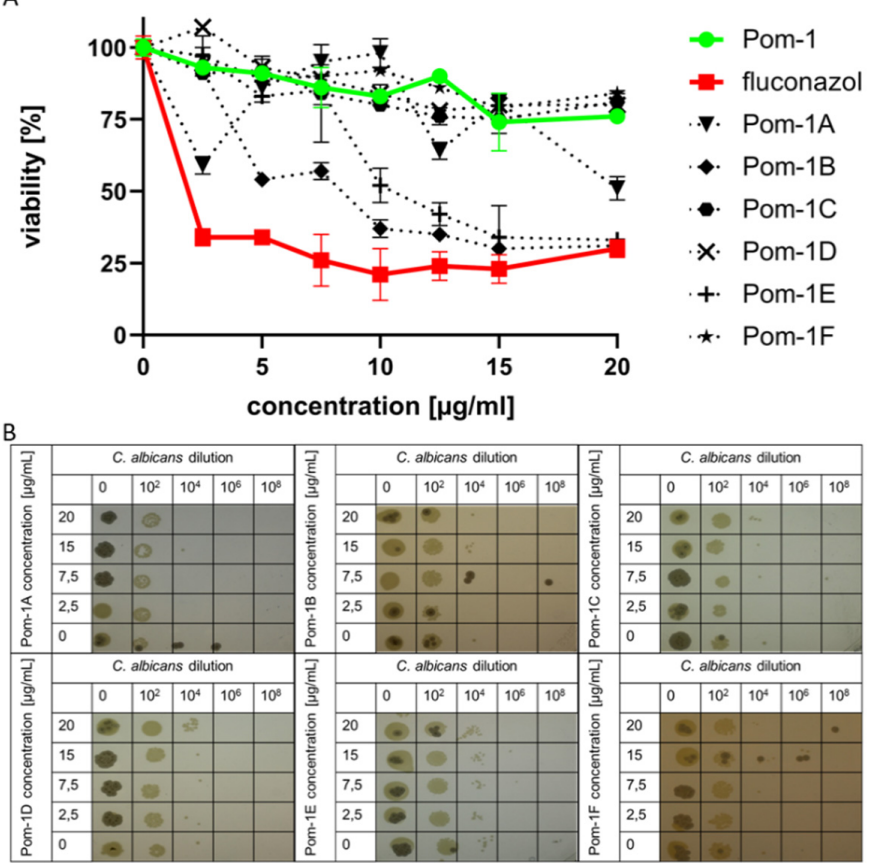

Figure 3. Antifungal activity of Pom-1A to F towards planktonic cells of C. albicans. (A) Determined dose-dependent effect of Pom-1 derivatives on cell viability by resazurin-reduction assay with fluconazole and Pom- 1 as the control agents. All experiments were performed in triplicate. (B) Plate spot assay after $24 \mathrm{~h}$ incubation of $C$. albicans cultures with defined cell number at various concentrations of Pom-1A to F. $10^{2}, 10^{4}, 10^{6}$, and $10^{8}$-fold dilutions of the original culture were added to agar and incubated for an additional $24 \mathrm{~h}$ at $37^{\circ} \mathrm{C}$. 
To confirm these results, a plate spot assay was performed on C. albicans planktonic cells treated with the different peptides (Figure 3B). For this purpose, $1 \mu \mathrm{L}$ cell suspension was taken from each well before adding the resazurin solution from the suspension microtiter plate. This sample was then diluted and was added to a Sabourand agar plate, which was then incubated for an additional $24 \mathrm{~h}$ for colony formation.

Here, we observed that colony formation decreased with the increase of peptide concentrations for Pom-1A, Pom-1B, and Pom-1D, and the use of higher dilutions of C. albicans samples, whereas Pom-1C, Pom-1D, and Pom-1F again showed only marginal colony formation.

\subsection{The Novel Peptides Inhibit C. albicans Biofilm-Formation}

The Pom- 1 wildtype peptide showed a significant activity against $C$. albicans biofilms [21]. In order to evaluate the potential of the novel Pom-1A-F peptides, the well established crystal violet assay for microbial cultures in microtiter plates was performed to quantify the biomass formed.

In contrast to their moderate activity against planktonic $C$. albicans cells in the tested concentration range, Pom- $1 \mathrm{~A}$ to $\mathrm{F}$ application resulted in up to $100 \%$ inhibition of biofilm formation already at low concentrations of the peptides. While the original Pom- 1 peptide has a semi inhibitory concentration $\left(\mathrm{IC}_{50}\right)$ of 3.8 , the derivatives had significantly lower values, which were very similar to the antifungal effect of fluconazole ( $\left.\mathrm{IC}_{50} 4.9 \mathrm{e}-032\right)$ (Figure 4). Pom-1B ( $\mathrm{IC}_{50}$ 0.008353), Pom-1C ( $\mathrm{IC}_{50}$ 0.08687), and Pom-1D (IC 50 4.9e-032) showed $100 \%$ inhibition of biofilm formation starting at a concentration of $2.5 \mu \mathrm{g} / \mathrm{mL}$, whereas Pom-1 did not even show $100 \%$ inhibition in the concentration range assayed. All other peptide derivatives (Pom-1A, E, and F) also did not show 100\% inhibition in the concentration range tested, but they still exhibited a higher antifungal activity against C. albicans biofilm than the original Pom- 1 peptide, calculated as $\mathrm{IC}_{50}$ of 0.9555 for Pom- $1 \mathrm{~A}$, 2.893 for Pom-1E, and 0.1570 for Pom-1F.

Microscopic analysis confirmed these results. C. albicans biofilms were treated with Pom-1, and its derivatives in comparison to an untreated bifilm control (Figure 4B). The latter control biofilm showed the highest density on the surface substratum, whereas a significant reduction was observed when the biofilms were formed in the presence of the Pom-1 wild type peptide. Compared to these control biofilms, Pom-1A to D showed a very similar cell density, whereas a slightly higher surface coverage was present for cultures incubated with Pom-1E and Pom-1F.

In summary, the results of the antifungal activity of the Pom-1 derivatives on planktonic and biofilm cells of $C$. albicans together with their physicochemical properties are shown in Table 1. 
A

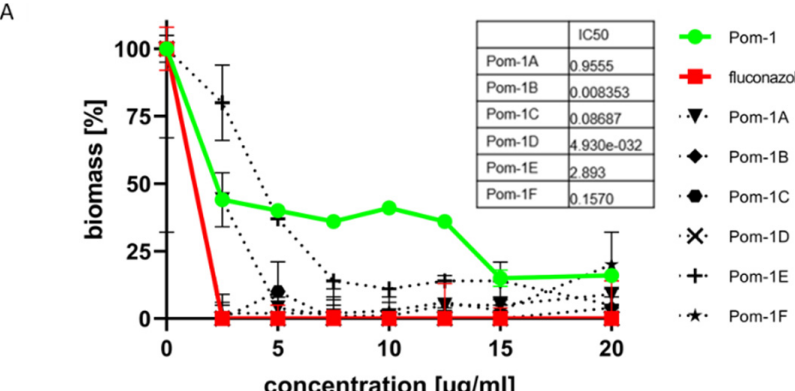

B
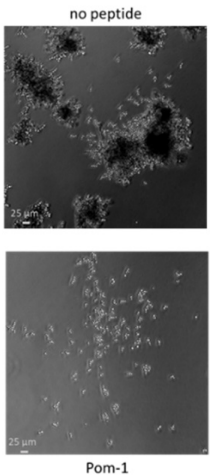
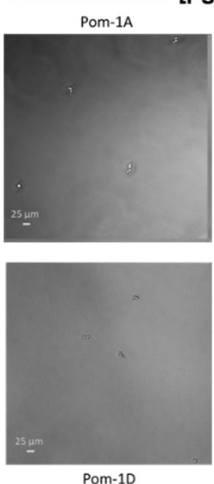
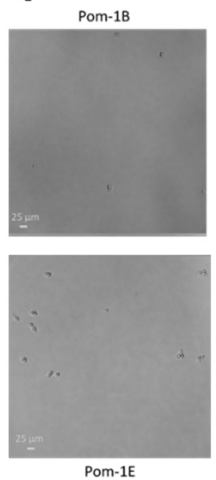
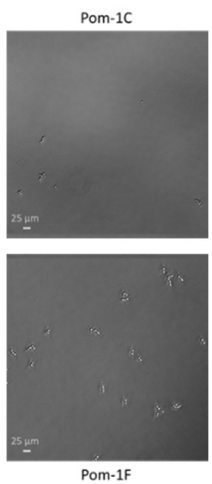

Figure 4. Antifungal activity of Pom-1A to F towards C. albicans biofilms. (A) Determined dosedependent effect of Pom-1 derivatives on biofilm mass by crystal violet assay with fluconazole and Pom-1 as the control agent. All experiments were performed in triplicate and error bars indicate standard deviations. (B) Microscopic analysis using a Leica DMi8 coded (Leica Microsystems CMS $\mathrm{GmbH}$, Wetzlar, Germany) microscope) of untreated C. albicans biofilm and biofilm treated with Pom- 1 and its derivatives $(20 \mu \mathrm{g} / \mathrm{mL})$ after $24 \mathrm{~h}$ of incubation at $37^{\circ} \mathrm{C}$ under transmitted light.

Table 1. Overview of the peptide properties calculated with ExPASy ProbParam [36] (peptide length, truncation of derivatives sequence compared to Pom-1 starting from C- and N-terimus, amphiphilic index, GRAVY (grand average of hydropathicity)), as well as the antimicrobial activities (against the planktonic cells at $20 \mu \mathrm{g} / \mathrm{mL}$ peptide concentration and biofilm based on $\mathrm{IC}_{50}$ values of the pathogenic yeast $C$. albicans) of the derivatives in comparison to Pom- 1 expressed in percent and the $\mathrm{IC}_{50}$ values of these peptides against biofilm formation of $C$. albicans.

\begin{tabular}{|c|c|c|c|c|c|c|c|}
\hline Peptide & Length [AS] & Truncation & $\begin{array}{l}\text { Amphipilic } \\
\text { Index [\%] }\end{array}$ & GRAVY [\%] & $\begin{array}{l}\text { IC }_{50} \text { Values } \\
\text { against } \\
\text { Biofilm } \\
\text { Formation }\end{array}$ & $\begin{array}{l}\text { Antimycrobial } \\
\text { Activity against } \\
\text { Planktonic } \\
\text { C. albicans Cells } \\
\text { [\%] at } 20 \mu \mathrm{g} / \mathrm{mL}\end{array}$ & $\begin{array}{c}\text { Antimicrobial } \\
\text { Activity against } \\
\text { C. albicans } \\
\text { Biofilm [\%] Based } \\
\text { on } \mathrm{IC}_{50} \text { Values }\end{array}$ \\
\hline Pom-1 & 34 & & 100 & 100 & 3.8 & 100 & 100 \\
\hline Pom-1A & 18 & $\mathrm{~N}-9 ; \mathrm{C}-7$ & 115 & 109 & 0.95 & 133 & 400 \\
\hline Pom-1B & 26 & $C-8$ & 89 & 89 & 0.008 & 160 & 47500 \\
\hline Pom-1C & 24 & $\mathrm{~N}-2 ; \mathrm{C}-8$ & 97 & 107 & 0.08 & 100 & 4750 \\
\hline Pom-1D & 19 & $N-9 ; C-6$ & 113 & 120 & $4.93 \times 10^{-32}$ & 97 & $8 \times 10^{33}$ \\
\hline Pom-1E & 25 & $C-9$ & 93 & 101 & 2.89 & 153 & 131 \\
\hline Pom-1F & 19 & $\mathrm{~N}-8 ; \mathrm{C}-7$ & 113 & 120 & 0.16 & 82 & 2375 \\
\hline
\end{tabular}

If results of the experiments (Figures 3 and 4) are compared to the peptide properties of the Pom-1 derivatives determined via ExPASy ProtParam (Table 1), it can be observed that there is no association between the amphiphilic character of the peptides and their antifungal activity. Compared to Pom-1 (assumed as 100\%), Pom-1B showed the lowest $(89 \%)$ and Pom-1D (113\%) the highest amphiphilic index compared to the six derivatives, and both of them are the most effective derivatives against biofilm formation. 


\subsection{Viability of Cell Culture}

As an important property determining the application potential of AMP, the cytotoxicity to human cells was initially tested by incubating Adeno carcinomic human alveolar basal epithelial cells A549 [24] and human dermal fibroblasts HDF [23] cell lines with all Pom-1 derivatives for $24 \mathrm{~h}$. These cells were used based on their easy handling (A549) and to test whether it would be possible to use these peptides in combination with wound dressings for further experiments in a basic skin model (HDF). Three controls served as the reference in these experiments. The viability of untreated cells was measured, as well as cell viability after treatment with the original Pom- 1 and surfactant Triton X-100 with known cytotoxicity added at concentrations of $2.5 \mu \mathrm{g} / \mathrm{mL}$ and $30 \mu \mathrm{g} / \mathrm{mL}$. A resazurin reduction assay was then performed to determine the cell viability, and the fluorescence of the reduction product resorufin was measured (Figure 5). The evaluation of the cytotoxicity was expressed as percent of viability. For this purpose, the measured values of the controls without reagents were taken as $100 \%$.

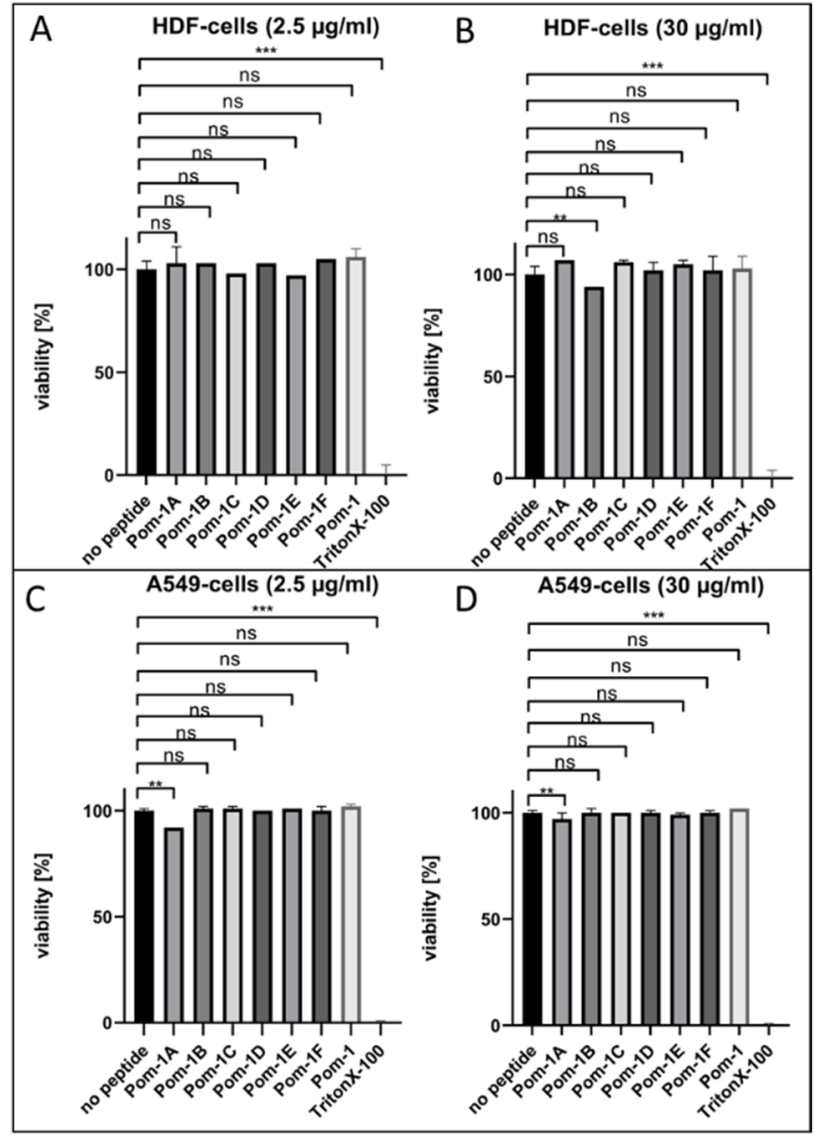

Figure 5. Analysis of cell viability for HDF and A549 cell lines without reagents and after the addition of Pom-1 derivatives, Pom-1 and Triton X-100. (A) Cell viability after the addition of $2.5 \mu \mathrm{g} / \mathrm{mL}$ of the respective reagent to HDF cells. (B) Cell viability in the presence of $30 \mu \mathrm{g} / \mathrm{mL}$ of the respective reagent to HDF. (C) Cell viability after application of $2.5 \mu \mathrm{g} / \mathrm{mL}$ of the respective reagent to A549 cells. (D) Cell viability after treatment with $30 \mu \mathrm{g} / \mathrm{mL}$ of the respective reagent to A549 cells. $p$ values $<0.05$ were considered as significant. ns denotes not siginificant; ${ }^{* *}$ denotes $p<0.01$; ${ }^{* *}$ denotes $p<0.001$.

These experiments showed only marginal reductions of cell viabilities compared to the untreated samples for the peptides Pom-1A starting at a concentration of $2.5 \mu \mathrm{g} / \mathrm{mL}$ on A549 cells (Figure 5C,D), and Pom-1B starting at a concentration of $30 \mu \mathrm{g} / \mathrm{mL}$ on HDF cells (Figure 5B). All other derivatives including the original peptide Pom-1 did not show any reduction in cell viability at the concentrations tested. 


\section{Discussion}

As clinical C. albicans isolates continuously increase their tolerance against various commercially used antimycotics, alternatives must be sought that support or even replace the commercially used therapeutic pathways. Meanwhile, clinical strains of $C$. albicans reach a minimum inhibitory concentration (MIC) of 0.5 to $64 \mu \mathrm{g} / \mathrm{mL}$ to fluconazole, 0.03 to $16 \mu \mathrm{g} / \mathrm{mL}$ to intraconazole (with these strains being considered resistant from $1 \mu \mathrm{g} / \mathrm{mL}$ ), and 0.125 to $4 \mu \mathrm{g} / \mathrm{mL}$ to amphotericin-B, which is considered as the golden standard for candidiasis [9,37-39]. Furthermore, treatment with these antifungals is associated with many side effects, according to the National Health Service of the United Kingdom. Thus, treatment with fluconazole often leads to headache, stomach pain, diarrhea, nausea, and vomiting, as well as skin rash [40]. When azoles are used for weeks to months after stem cell transplantation, for example, they can even lead to hepatotoxicity and hormonal side effects such as impotence, as well as muscle and nerve disfunction. Other known side effects of the azole drug group include pancreatitis, phototoxic reactions, and peripheral neuropathy [41]. In addition, amphotericin-B is nephrotoxic at high doses and can cause nausea, vomiting, fever, hypoxia, and other side effects [42]. Thus, every molecule added to the portfolio of promising antifungal drugs in the fight against strains with pronounced resistance against the traditional compounds can be regarded as an important step towards possible treatment strategies involving the novel drugs in combination with the standard molecules to reduce the required high concentrations and thus their severe side effects.

The antifungal effect of the wildtype Pom- 1 peptide against planktonic $C$. albicans cells could be slightly improved by the alterations introduced with the derivatives Pom-1A, Pom-1B, and Pom-1E, which have similar activities like the reference fungicide fluconazole in the tested concentration range $(0-20 \mu \mathrm{g} / \mathrm{mL})$. All derivatives, more importantly, represented considerable or impressive improvements of the inhibition of C. albicans biofilm formation (Table 1).

Although the exact molecular mechanisms behind AMP activities is accepted to be currently still not comprehensively understood, two main ways of action are in discussion [43-45]. In recent years AMPs appeared to be active intracellularly, which were considered to exert their antimicrobial activity by binding to specific targets within the cell [46]. On the other hand, there are the more classical membrane-active AMPs. This group is thought to have only activities based exclusively on their physicochemical properties, which are suited to assemble into macromolecular structures that interact with biomembranes to destabilize them and to compromise their full structural and functional integrity forming nano-scale pores [47]. The key factors in this mechanism are thought to have been identified as the cationic, amphiphilic, and hydrophobic character of the respective AMPs $[17,18]$. Due to their high hydrophobicity and amphiphilicity, as well as the low cationic character of the peptides, they can interact well with the negatively charged but overall hydrophobic pathogen membrane [46].

Bioinformatic analysis showed an improvement in the amphiphilic index for derivatives $\mathrm{A}, \mathrm{D}$, and $\mathrm{F}$, and an improvement in the GRAVY value for all derivatives except Pom-1B (Table 1).

Based on our results, it is reasonable to suspect that the Pom- 1 derivatives do not act like conventional membrane-active AMPs, but more like $\mathrm{Cm}$ - $\mathrm{p} 5$ derivatives, which we have recently described to probably act via a novel mechanism at the membrane [48]. As the peptides are only moderately effective against planktonic cells, but are very effective at preventing biofilm formation, we assume that the peptides likely do not form pores, but rather aggregate on the pathogenic membrane ("carpet-model" [46]), thereby preventing biofilm formation. To suspect a different mode of action is also supported by the fact that Pom-1 and also its derivatives show only marginal cytotoxic effects on human cells, suggesting that the simple physical formation of harmful pores in the biomembranes is not the key effect. To elucidate the molecular mechanism behind this potential cell-cell and/or cell-substrate interaction disturbed by the (peptide) complexes will be part of in-depth follow up studies. Nevertheless, with an improvement of anti-biofilm activity against 
C. albicans of several orders of magnitude for Pom-1B, C and D, we developed peptides that are similarly effective to fluconazole as one of the traditional standard therapeutics. Although the extent of the development of potential resistance against these peptides needs to be carefully determined, we believe that their tendency to be selective towards resistance can be expected to be moderate. Thus, these novel peptides maybe a promising starting point for further optimization, and thus may represent attractive lead structures on the way towards potent future peptide-based anti-C. albicans therapeutics.

\section{Conclusions}

Classic antifungal drugs have many negative side effects and long-term therapy is often required [40,47]. As antifungal resistance is increasing, higher concentrations are applied and aggravate this problem. Small AMPs with a high antifungal activity and low cell toxicity could therefore be a strong resource in the fight against candidiasis. In this study, we found out that optimization of the naturally occurring AMP Pom-1 by shortening of the original sequence improved antifungal activity against planktonic cells, as well as against biofilm formation of the yeast C. albicans, which causes up to $95 \%$ of all candidiasis [1]. While derivatives Pom-1B to D show an excellent antifungal activity against the biofilm formation of C. albicans, only Pom-1B and Pom-1E show a slightly improved antifungal activity against planktonic cells on $C$. albicans yeast cells in comparison to Pom1. Based on the low cytotoxicity, it is assumed that these peptides do not develop their antimicrobial activity by pore formation like conventional AMPs, but according to the "carpet model" [46], and bind to specific targets on the pathogenic membrane and thus prevent cell-cell interaction and biofilm formation. This assumption creates the incentive to conduct further studies to provide the exact mechanism of action of these novel AMPs.

For further optimization, such as the generation of a cyclic version or a multivalent peptide, Pom-1B could be used considering its structural features. Moreover, it is not yet known how these peptide derivatives act in combination with each other or with conventional drugs.

Supplementary Materials: The following supporting information can be downloaded at: https: / / www.mdpi.com/article/10.3390/pharmaceutics14020318/s1, Table S1: Six peptides (Pom-1A to F).

Author Contributions: Conceptualization, F.R.; methodology, V.A., A.-K.K., M.K. and I.K.;validation, V.A., A.-K.K., M.K., I.K., and F.R.; investigation, V.A., A.-K.K., M.K., I.K., J.A.P.-E., F.M.-V., A.R., and F.R.; resources, F.R., A.J.O.-G., T.W., and L.S.; writing-original draft preparation, V.A., A.-K.K., and F.R.; writing-review and editing, V.A.; visualization, V.A. and J.A.P.-E.; supervision, F.R. and L.S.; funding acquisition, F.R., A.J.O.-G., T.W., and L.S. All authors have read and agreed to the published version of the manuscript.

Funding: This work was supported the Ministry of Science, Research, and Arts of the state of BadenWürttemberg in the framework of the PhD program: pharmaceutical biotechnology, the BadenWürttemberg Stiftung in the framework of "Bioinspired material synthesis" and "Biofunktionelle Materialien und Oberflächen" (Nano-Mem-to-Tech, BiofMO_005), and the European Union project "Horizon 2020" (no. 686271) in the framework "AD-gut". This work was supported by grants from the Ministry of Science, Research, and the Arts of Baden-Württemberg (MWK; Förderkennzeichen: 7533-10-5-186A and 7533-10-5-190) and the German Research Society (DFG) project 465229237 and CRC1279 (Ex-ploiting the Human Peptidome for Novel Antimicrobial and Anticancer Agents), the Alexander von Humboldt-Stiftung, Research Group Linkage Program (No. 1160914), Federal Ministry of Education and Research (BMBF-WTZ-DLR, GermanyCuba, 2018-2020; BMBF/DLR 01DN18009) and DAAD (Bonn, Germany) with funds from the German Federal Foreign Ministry (AA), project-ID 57592717 (DAAD Helath Center GLACIER). 
Institutional Review Board Statement: Not applicable.

Informed Consent Statement: Not applicable.

Acknowledgments: We gratefully acknowledge Merve Karacan and Nico Preising (CFP Ulm) for peptide synthesis.

Conflicts of Interest: The authors declare no conflict of interest.

\section{References}

1. Sobel, J.D. Vulvovaginal candidosis. Lancet 2007, 369, 1961-1971. [CrossRef]

2. Ramage, G.; Martãnez, J.P.; Lã Pez-Ribot, J.L. Candida biofilms on implanted biomaterials: A clinically significant problem. FEMS Yeast Res. 2006, 6, 979-986. [CrossRef] [PubMed]

3. Kumamoto, C.A. Candida biofilms. Curr. Opin. Microbiol. 2002, 5, 608-611. [CrossRef]

4. Borman, A.M.; Szekely, A.; Johnson, E.M. Isolates of the emerging pathogen Candida auris present in the UK have several geographic origins. Med. Mycol. 2017, 55, 563-567. [CrossRef] [PubMed]

5. Sherry, L.; Ramage, G.; Kean, R.; Borman, A.; Johnson, E.M.; Richardson, M.D.; Rautemaa-Richardson, R. Biofilm-Forming Capability of Highly Virulent, Multidrug-Resistant Candida auris. Emerg. Infect. Dis. 2017, 23, 328-331. [CrossRef] [PubMed]

6. Xie, Z.; Thompson, A.; Sobue, T.; Kashleva, H.; Xu, H.; Vasilakos, J.; Dongari-Bagtzoglou, A. Candida albicans Biofilms Do Not Trigger Reactive Oxygen Species and Evade Neutrophil Killing. J. Infect. Dis. 2012, 206, 1936-1945. [CrossRef]

7. Pierce, C.G.; Vila, T.; Romo, J.A.; Montelongo-Jauregui, D.; Wall, G.; Ramasubramanian, A.; Lopez-Ribot, J.L. The Candida albicans Biofilm Matrix: Composition, Structure and Function. J. Fungi 2017, 3, 14. [CrossRef]

8. Pappas, P.G.; Kauffman, C.A.; Andes, D.; Benjamin, D.K., Jr.; Calandra, T.F.; Edwards, J.E., Jr.; Filler, S.G.; Fisher, J.F.; Kullberg, B.J.; Ostrosky-Zeichner, L.; et al. Clinical Practice Guidelines for the Management of Candidiasis: 2009 Update by the Infectious Diseases Society of America. Clin. Infect. Dis. 2009, 48, 503-535. [CrossRef]

9. Pappas, P.G.; Kauffman, C.A.; Andes, D.R.; Clancy, C.J.; Marr, K.A.; Ostrosky-Zeichner, L.; Reboli, A.C.; Schuster, M.G.; Vazquez, J.A.; Walsh, T.J.; et al. Clinical Practice Guideline for the Management of Candidiasis: 2016 Update by the Infectious Diseases Society of America. Clin. Infect. Dis. 2015, 62, e1-e50. [CrossRef]

10. Nett, J.; Lincoln, L.; Marchillo, K.; Massey, R.; Holoyda, K.; Hoff, B.; VanHandel, M.; Andes, D. Putative Role of $\beta-1,3$ Glucans in Candida albicans Biofilm Resistance. Antimicrob. Agents Chemother. 2007, 51, 510-520. [CrossRef]

11. Nett, J.E.; Crawford, K.; Marchillo, K.; Andes, D. Role of Fks1p and Matrix Glucan in Candida albicans Biofilm Resistance to an Echinocandin, Pyrimidine, and Polyene. Antimicrob. Agents Chemother. 2010, 54, 3505-3508. [CrossRef] [PubMed]

12. Nett, J.E.; Sanchez, H.; Cain, M.; Andes, D. Genetic Basis of Candida Biofilm Resistance Due to Drug-Sequestering Matrix Glucan. J. Infect. Dis. 2010, 202, 171-175. [CrossRef] [PubMed]

13. Silva, S.; Negri, M.; Henriques, M.; Oliveira, R.; Williams, D.W.; Azeredo, J. Candida glabrata, Candida parapsilosis and Candida tropicalis: Biology, epidemiology, pathogenicity and antifungal resistance. FEMS Microbiol. Rev. 2012, 36, $288-305$. [CrossRef] [PubMed]

14. Taff, H.T.; Nett, J.E.; Zarnowski, R.; Ross, K.M.; Sanchez, H.; Cain, M.; Hamaker, J.; Mitchell, A.P.; Andes, D. A Candida BiofilmInduced Pathway for Matrix Glucan Delivery: Implications for Drug Resistance. PLoS Pathog. 2012, 8, e1002848. [CrossRef]

15. Mitchell, K.F.; Zarnowski, R.; Andes, D.R. Fungal Super Glue: The Biofilm Matrix and Its Composition, Assembly, and Functions. PLoS Pathog. 2016, 12, e1005828. [CrossRef]

16. CDC's Antibiotic Resistance Threats in the United States (2019 AR Threats Report). 2019. Available online: https:/ /www.cdc. gov / drugresistance/biggest-threats.html (accessed on 14 December 2021).

17. Nakatsuji, T.; Gallo, R.L. Antimicrobial Peptides: Old Molecules with New Ideas. J. Investig. Dermatol. 2012, 132, 887-895. [CrossRef]

18. Kumar, P.; Kizhakkedathu, J.N.; Straus, S.K. Antimicrobial Peptides: Diversity, Mechanism of Action and Strategies to Improve the Activity and Biocompatibility In Vivo. Biomolecules 2018, 8, 4. [CrossRef]

19. Hancock, R.E.W.; Haney, E.F.; Gill, E.E. The immunology of host defence peptides: Beyond antimicrobial activity. Nat. Rev. Immunol. 2016, 16, 321-334. [CrossRef]

20. Gonzalez Garcia, M.; Rodriguez, A.; Alba, A.; Vazquez, A.A.; Morales Vicente, F.E.; Perez-Erviti, J.; Spellerberg, B.; Stenger, S.; Grieshober, M.; Conzelmann, C.; et al. New Antibacterial Peptides from the Freshwater Mollusk Pomacea poeyana (Pilsbry, 1927). Biomolecules 2020, 10, 1473. [CrossRef]

21. Raber, H.; Sejfijaj, J.; Kissmann, A.-K.; Wittgens, A.; Gonzalez-Garcia, M.; Alba, A.; Vázquez, A.; Vicente, F.M.; Erviti, J.; Kubiczek, D.; et al. Antimicrobial Peptides Pom-1 and Pom-2 from Pomacea poeyana Are Active against Candidaauris, C. parapsilosis and C. albicans Biofilms. Pathogens 2021, 10, 496. [CrossRef]

22. Kemperman, R.; Kuipers, A.; Karsens, H.; Nauta, A.; Kuipers, O.; Kok, J. Identification and Characterization of Two Novel Clostridial Bacteriocins, Circularin A and Closticin 574. Appl. Environ. Microbiol. 2003, 69, 1589-1597. [CrossRef] [PubMed]

23. Okita, K.; Matsumura, Y.; Sato, Y.; Okada, A.; Morizane, A.; Okamoto, S.; Hong, H.; Nakagawa, M.; Tanabe, K.; Tezuka, K.-I.; et al. A more efficient method to generate integration-free human iPS cells. Nat. Methods 2011, 8, 409-412. [CrossRef] [PubMed] 
24. Lieber, M.; Todaro, G.; Smith, B.; Szakal, A.; Nelson-Rees, W. A continuous tumor-cell line from a human lung carcinoma with properties of type II alveolar epithelial cells. Int. J. Cancer 1976, 17, 62-70. [CrossRef] [PubMed]

25. Monroe, M. Protein Digestion Simulator, 2.2.6794.30874; Pacific Northwest National Laboratroy, Department of Energy. Available online: https:/ / www.pnnl.gov / science/highlights/highlight.asp?id=282 (accessed on 4 August 2021).

26. Veltri, D.; Kamath, U.; Shehu, A. Deep learning improves antimicrobial peptide recognition. Bioinformatics 2018, 34, $2740-2747$. [CrossRef] [PubMed]

27. Meher, P.K.; Sahu, T.K.; Saini, V.; Rao, A.R. Predicting antimicrobial peptides with improved accuracy by incorporating the compositional, physico-chemical and structural features into Chou's general PseAAC. Sci. Rep. 2017, 7, srep42362. [CrossRef]

28. Clinical and Laboratory Standards Institute. Reference Method for Broth Dilution Antifungal Susceptibility Testing of Filamentous Fungi-M38-A2; Clinical and Laboratory Standards Institute: Annapolis Junction, MD, USA, 2008; Volume 28, ISBN 1-56238-668-9.

29. Fai, P.B.; Grant, A. A rapid resazurin bioassay for assessing the toxicity of fungicides. Chemosphere 2009, 74, 1165-1170. [CrossRef]

30. Hilgers, F.; Bitzenhofer, N.L.; Ackermann, Y.; Burmeister, A.; Grünberger, A.; Jaeger, K.-E.; Drepper, T. Genetically Encoded Photosensitizers as Light-Triggered Antimicrobial Agents. Int. J. Mol. Sci. 2019, 20, 4608. [CrossRef]

31. Jose, A.; Coco, B.J.; Milligan, S.; Young, B.; Lappin, D.F.; Bagg, J.; Murray, C.; Ramage, G. Reducing the incidence of denture stomatitis: Are denture cleansers sufficient? J. Prosthodont. 2010, 19, 252-257. [CrossRef]

32. O'Toole, G.A. Microtiter Dish Biofilm Formation Assay. J. Vis. Exp. 2011, 47, 2437. [CrossRef]

33. Negri, M.; Gonçalves, V.; Silva, S.; Henriques, M.; Azeredo, J.; Oliveira, R. Crystal violet staining to quantity Candida adhesion to epithelial cells. Br. J. Biomed. Sci. 2010, 67, 120-125. [CrossRef]

34. O’Toole, G.; Kaplan, H.B.; Kolter, R. Biofilm Formation as Microbial Development. Annu. Rev. Microbiol. 2000, 54, 49-79. [CrossRef] [PubMed]

35. Sherry, L.; Rajendran, R.; Lappin, D.F.; Borghi, E.; Perdoni, F.; Falleni, M.; Tosi, D.; Smith, K.; Williams, C.; Jones, B.; et al. Biofilms formed by Candida albicans bloodstream isolates display phenotypic and transcriptional heterogeneity that are associated with resistance and pathogenicity. BMC Microbiol. 2014, 14, 182. [CrossRef] [PubMed]

36. Gasteiger, E.; Hoogland, C.; Gattiker, A.; Duvaud, S.; Wilkins, M.R.; Appel, R.D.; Bairoch, A. Protein Identification and Analysis Tools on the ExPASy Server. In The Proteomics Protocols Handbook; Walker, J.M., Ed.; Humana Press: New York, NY, USA, 2005; pp. 571-607.

37. Maebashi, K.; Niimi, M.; Kudoh, M.; Fischer, F.J.; Makimura, K.; Niimi, K.; Piper, R.J.; Uchida, K.; Arisawa, M.; Cannon, R.; et al. Mechanisms of fluconazole resistance in Candida albicans isolates from Japanese AIDS patients. J. Antimicrob. Chemother. 2001, 47, 527-536. [CrossRef]

38. Watamoto, T.; Samaranayake, L.; Jayatilake, J.; Egusa, H.; Yatani, H.; Seneviratne, C. Effect of filamentation and mode of growth on antifungal susceptibility of Candida albicans. Int. J. Antimicrob. Agents 2009, 34, 333-339. [CrossRef] [PubMed]

39. Cordeiro, R.A.; Teixeira, C.E.C.; Brilhante, R.S.N.; Castelo-Branco, D.; Paiva, M.A.N.; Leite, J.J.G.; Lima, D.T.; Monteiro, A.J.; Sidrim, J.J.C.; Rocha, M.F.G. Minimum inhibitory concentrations of amphotericin B, azoles and caspofungin against Candida species are reduced by farnesol. Med. Mycol. 2013, 51, 53-59. [CrossRef] [PubMed]

40. National Health Service UK. Fluconazole: Medicine to Treat Fungal Infections Including Nail Infections-NHS. 2020. Available online: https:/ / www.nhs.uk/medicines/fluconazole/ (accessed on 4 August 2021).

41. Benitez, L.L.; Carver, P.L. Adverse Effects Associated with Long-Term Administration of Azole Antifungal Agents. Drugs 2019, 79, 833-853. [CrossRef]

42. Laniado-Laborín, R.; Cabrales-Vargas, M.N. Amphotericin B: Side effects and toxicity. Rev. Iberoam. De Micol. 2009, 26, $223-227$. [CrossRef]

43. Otvos, L. Antibacterial peptides and proteins with multiple cellular targets. J. Pept. Sci. 2005, 11, 697-706. [CrossRef]

44. Mookherjee, N.; Lippert, D.N.D.; Hamill, P.; Falsafi, R.; Nijnik, A.; Kindrachuk, J.; Pistolic, J.; Gardy, J.; Miri, P.; Naseer, M.; et al. Intracellular Receptor for Human Host Defense Peptide LL-37 in Monocytes. J. Immunol. 2009, 183, 2688-2696. [CrossRef]

45. Chen, L.; Harrison, S. Cell-penetrating peptides in drug development: Enabling intracellular targets. Biochem. Soc. Trans. 2007, 35, 821-825. [CrossRef]

46. Cudic, M.; Otvos, L. Intracellular targets of antibacterial peptides. Curr. Drug Targets 2002, 3, 101-106. [CrossRef] [PubMed]

47. Madani, F.; Lindberg, S.; Langel, Ü.; Futaki, S.; Gräslund, A. Mechanisms of Cellular Uptake of Cell-Penetrating Peptides. J. Biophys. 2011, 2011, 414729. [CrossRef] [PubMed]

48. Kubiczek, D.; Raber, H.; Gonzalez-García, M.; Morales-Vicente, F.; Staendker, L.; Otero-Gonzalez, A.J.; Rosenau, F. Derivates of the Antifungal Peptide Cm-p5 Inhibit Development of Candida auris Biofilms In Vitro. Antibiotics 2020, 9, 363. [CrossRef] [PubMed] 